New Jersey History 125:2

\title{
"Ye relief of ye poor of sd towne": Poverty and Localism in Eighteenth-Century New Jersey
}

\author{
John A. Grigg ${ }^{1}$
}

\begin{abstract}
In keeping with all the colonies of British North America in the eighteenth century, New Jersey residents grappled with the poor in their midst. Since the early seventeenth century, people in Britain and in its colonies had accepted that even hard working people could slip into poverty through no fault of their own. This, in turn, meant that officials and townspeople recognized the need for some form of poor relief either through providing work options for the able poor or through direct relief for those unable to work. In eighteenth-century New Jersey, provincial poor laws and local town practices imitated, to some extent, common practices in Britain. However, these practices were modified by both the character of New Jersey settlement and by the broad requirements of provincial legislation which allowed for a significant degree of local interpretation. Thus, poor relief in New Jersey towns was carried out on a personal level and was influenced by both compassion and pragmatism.
\end{abstract}

In recent years, the study of poverty has been one of the more fruitful areas of research for historians of early America. A steady flow of analyses of the poor have emerged providing understanding of the extent of poverty in the British colonies, the way in which it waxed and waned according to various local, regional, and transatlantic trends, and how individuals, communities, and colonies attempted to alleviate its impact on both their own lives and the lives of those around them. As the various colonies became more aware of the extent of poverty among their residents, efforts at poor relief developed a greater cohesion and legal structure. By the eighteenth century, most of the British colonies in North America made at least some attempt to follow legal and social precedents established in Great Britain, although these were commonly modified by local constraints and customs. ${ }^{2}$

Eighteenth-century New Jersey was no exception when it came to the occurrence of poverty. Even in this province, which its governor described in 1748 as "the best country I have seen for

\footnotetext{
${ }^{1}$ John A. Grigg is the chair of the graduate program in the Department of History at the University of NebraskaOmaha.

${ }^{2}$ The literature on poverty and poor relief is quite substantial and would be impossible to list in detail. A brief sample of the available works includes: Gary B. Nash, The Urban Crucible: The Northern Seaports and the Origins of the American Revolution, abridged ed. (Cambridge: Harvard University Press, 1986); Sharon V. Salinger, "To serve well and faithfully": Labor and indentured servants in Pennsylvania, 1682-1800 (Cambridge: Cambridge University Press, 1987); Stephen Innes, ed., Work and Labor in Early America (Chapel Hill: University of North Carolina Press for the Institute of Early American History and Culture, 1988); Ruth Wallis Herndon, Unwelcome Americans: living on the margin in early New England (Philadelphia: University of Pennsylvania Press, 2001); Robert E. Cray, Jr., Paupers and Poor Relief in New York City and Its Rural Environs, 1700-1830 (Philadelphia: Temple University Press, 1988; Charles R. Lee, "Poor Relief and the Massachusetts Community, 1620-1715," The New England Quarterly Vol. 55 No. 4 (Dec., 1982), 564-585; Tim Lockley, "Rural Poor Relief in Colonial South Carolina," The Historical Journal Vol. 48, No. 4 (2005), 955-976; Lois Green Carr and Russell R. Menard, "Wealth and Welfare in Early Maryland: Evidence from St. Mary's County," The William and Mary Quarterly Vol. 56, No. 1 (Jan., 1999), 95-120.
} 
men of middling fortunes," ill fortune or ill health could strike at those of "middling fortune," regardless of their work ethic, and hamper or prevent them being able to provide for themselves and their families. ${ }^{3}$ The provincial assembly passed several laws aimed at alleviating poverty, but these were long on intent and short on specifics, essentially placing the mechanisms for poor relief in the hands of local communities. For the most part, this meant that the scattered townships in the colony took on the responsibility for the poor in their midst. On occasion, county freeholders, or even the courts, had to step in to adjudicate disputes between towns or to ensure that legal requirements were met. But, this was very much the exception rather than the norm: overwhelmingly the poor were cared for by their home community. While this paralleled - but did not exactly replicate - the practice in Britain and other British North American colonies, it also meant that poverty was not normally an abstract issue but one that involved friends and neighbors. Local leaders, confronted with the poverty of people they had known for most of their lives, frequently found solutions that were both compassionate and pragmatic.

\section{Legislating Poor Relief}

State-sponsored approaches to poor relief emerged in late sixteenth-century England as society's leaders "discovered" a new group of poor in their midst. Traditionally, English society had recognized two broad groups of poor. The first was the deserving poor -- those unable to work and whom were appropriate recipients of charity. The second group were those known as vagrants: people, so it was held, who could work but who embarked instead on a wandering lifestyle that was meant to avoid the responsibility of settled productivity. Such people had almost always been the targets of punishment and of being "warned out" (an official notification that the town would not provide for their support should they be unable to support themselves) rather than being the objects of charity. Then, in the late sixteenth century, a number of censuses revealed, for the first time to England's ruling classes, the existence of a third group of poor - the laboring poor. These were people who were both willing and able to work but who still lived close to the bone either because of the meagerness of their income or because they were unable to find regular work. For the ruling class, the working poor were appropriate recipients of welfare because they were deserving of it and because they represented a potential source of unrest should their poverty appear to them to be insurmountable. ${ }^{4}$

It was largely in response to this revelation of the existence of the working poor that parliament passed the Elizabethan Poor Law in 1601. As a number of historians have noted, to a substantial extent the Poor Law reflected the newly developed cultural consensus regarding poverty and so, in many ways, it codified local and ad hoc efforts to combat poverty that had been taking place in communities throughout the realm. In the first instance, it was generally held, families held the initial responsibility for aiding the destitute. Thus, the poor law was designed to operate when family assistance was unavailable or had reached its limits. The Poor Law designated the

\footnotetext{
${ }^{3}$ Jonathan Belcher to unknown correspondent, November 14, 1748. Jonathan Belcher Collection, Box 1, Folder 21, Department of Rare Books and Special Collections, Princeton University Library, used by permission.

${ }^{4}$ Steve Hindle, The State and Social Change in Early Modern England, c.1500-1640 (New York: Palgrave, 2000), 37-59; Geoffrey W. Oxley, Poor Relief in England and Wales, 1601-1834 (North Pomfret, Vermont: David \& Charles, 1974), 14-17; Steve Hindle, On the Parish? The Micro-Politics of Poor Relief in Rural England c. 15501750 (New York: Oxford University Press, 2004).
} 
parish as the administrative unit through which public poor relief would be dispensed. In so doing, as historian Geoffrey Oxley observed, Parliament "placed the responsibility [for poor relief] on those who could be expected to recognize the moral claims upon them." Although not a perfect solution, it did mean that the cost of was kept low and that, at least in theory, those providing relief and those receiving it were known to one another. As historian Steve Hindle has observed, the parish "effectively became a welfare republic." 5

One of the most important provisions of the law was the creation of the office of Overseer of the Poor. The law required that this office be filled by two to four "substantial Householders" of the parish, who were responsible for coordinating local poor relief by carrying out the provisions of the new law. By specifying substantial householders, the law was essentially asking the leaders of local communities to use their influence to determine the appropriate level of poor relief. The law was designed to provide relief for both the laboring poor and the deserving poor. Among its provisions was a strong encouragement to the Overseers of the Poor to bind out as apprentices the children of those parents who were "thought [not] able to keep them," in order to alleviate some of the burden on the laboring poor. A similar goal was in mind with the requirement that the Overseers lay in a "convenient Stock of Flax, Hemp, Wool, Thread, Iron and other necessary Ware and Stuff" in order to set the poor to work if they could find no work for themselves. But, to aid those unable to work, parishes were also expected to raise money to provide for the "necessary Relief of the Lame, Impotent, Old, Blind" and others physically incapable of working. ${ }^{6}$

Although the process of poor relief established by the 1601 act was subject to a number of refinements in subsequent decades, there was no substantial alteration to its practice in Britain for almost two hundred years. It was this approach to relief that was paralleled - but not precisely duplicated - in British colonies such as New Jersey. In general, Britons and colonists believed that both the laboring poor and those unable to work were deserving of some form of public relief. The general parameters of such relief were laid down by a central government, but the actual implementation was to be coordinated by local authorities. ${ }^{7}$

\footnotetext{
${ }^{5}$ Hindle, State and Social Change, 11, 12, 48-58, 147, quote on 147; Oxley, Poor Relief, 34- 42, quote on 34. Of course, like any government program, the system did not work as it should in every place. Nonetheless, it was effective in many, perhaps the majority, of regions. For discussion of some of the problems, see Hindle, State and Social Change, 153-162 and Oxley, Poor Relief, 34-42.

6 "An Act for Relief of the Poor," in Ellwood P. Cubberly, Readings in the History of Education (New York: Houghton Mifflin, 1920), 268-271; Oxley, Poor Relief, 14-21; Hindle, State and Social Change, 153-162; Hindle, On the Parish? 365-369.

${ }^{7}$ The evolution of the Poor Laws between 1601 and 1834 included a number of refinements and clarifications but none of them altered the nature of the law in any substantial way until 1795. The number of works describing poor relief in the colonies is voluminous but examples include: Rhys Isaac, The Transformation of Virginia, 1740-1790 (Chapel Hill: The University of North Carolina Press for the Omohundro Institute of Early American History and Culture, 1999), 65; Herndon, Unwelcome Americans; Cray, Paupers and Poor Relief; Lee, "Poor Relief and the Massachusetts Community"; Lockley, "Rural Poor Relief in Colonial South Carolina,"; Carr and Menard, "Wealth and Welfare in Early Maryland."
} 
Information on poor relief in New Jersey prior to the establishment of royal government is limited, but most commentators agree that the primary burden of caring for the poor fell on the family and the church. However, even in the seventeenth century, there was sometimes occasion for public relief. West Jersey passed a law in 1671 permitting the establishment of workhouses and another in 1676 providing for the support of orphans from public funds. East Jersey passed general laws for poor relief in 1682 and the town of Newark made its first provision for public care of the poor, in this case a single person, in 1683. Among the lengthy instructions to Lord Cornbury from Queen Anne in 1703, was an encouragement to the new governor to raise stocks and build workhouses "in convenient places for the employing of poor and indigent people." 8

The first act specifically designed to provide relief for New Jersey's poor was passed by the reunified colony's fourth assembly in 1709. In keeping with British law, it placed the burden of care on local communities in particular requiring the appointment of Overseers of the Poor to administer poor relief at the local level. However, since there was no established church, there was no parish structure nor was there a system of parish tithes by which the poor could be supported. The Assembly therefore designated the "Townships or Precincts" as the means by which poor relief would be assessed. It also created the office of Assessor, the occupant/s of which would be responsible for assessing a tax on the inhabitants of the towns in order to fund poor relief. Although the law made provision for both the working poor and those unable to work, as in Britain the process by which this would be carried out was left largely to the towns themselves. Although poor relief was addressed in a number of laws over the next seventy years or so, the structure created in 1709 was essentially unchanged through the rest of the colonial period. ${ }^{9}$

\section{Gainful Employment: Work as Poor Relief}

The 1709 law began by declaring that it was "necessary that the Poor should be relieved by the Publick, where they cannot relieve themselves, nor are not able to work for the Support." The law specifically instructed Overseers of the Poor to place the children of poor families into apprenticeships, requiring them to "put forth such Poor Children as have no Parents, and such as their Parents are not able to maintain." 10 This emphasis on binding out the children of the poor reflected its return to common usage in eighteenth-century Britain after declining through the latter part of the seventeenth century. Historian Steve Hindle has noted that apprenticeship in Britain had two goals. It was to "reduce the burden on [poor] rates by alleviating life-cycle

\footnotetext{
${ }^{8}$ Martin W. Stanton, History of Public Poor Relief in New Jersey, 1609 - 1934 (New York: n.p., 1934), 2, 3, 16, 17; James Leiby, Charity and Correction in New Jersey: A History of State Welfare Institutions (New Brunswick: Rutgers University Press, 1967), 5, 6; Paul Tutt Stafford, Government and the Needy: A Study of Public Assistance in New Jersey (Princeton: Princeton University Press, 1941), 25; "Instructions from Queen Anne to Lord Cornbury as Governor of New Jersey," Archives of the State of New Jersey, ${ }^{\text {st }}$ Series, (Newark, 1881), II: 506 - 536, quote on 532.

9 "An Act for the Relief of the Poor," Bernard Bush, comp., Laws of the Royal Colony of New Jersey 5 vols. (Trenton: New Jersey State Library, 1974-1986), II: 55, 56. In 1704, “An Act for Suppressing of Immorality within this Province of New Jersey" (1704) allowed for fines levied on certain actions to be handed over to the overseers of the poor although there had been no legislation creating the office. Presumably many of the towns had created the position themselves. Paragraphs addressing poor relief were, on occasion, added to other acts of the Assembly, but the next major law on poor relief was passed in 1754. See: "An ACT for the Settlement and Relief of the Poor," Bush, comp., Laws, III: 599-615.

10 “Act for the Relief of the Poor," Laws, II: 55, 56.
} 
poverty" as well as being designed to provide a benefit to the children involved. To this end, the Overseers of the Poor were expected to take care in selecting masters in order that both these goals would be met. ${ }^{11}$

The central role played by the Overseers is evident in the majority of surviving New Jersey indentures. Most (although not all) indentures were drawn up under the authority of the Overseers of the Poor, and included the names of the two parties, the child's parents, and the date of termination which was usually based on the child's age. The apprentice was required to observe certain "moral" provisions - again similar to those in England - such as not visiting taverns or inns, refraining from playing cards or dice, and abstaining from fornication. There was also usually a provision forbidding the apprentice from contracting marriage during the period of the apprenticeship. Masters, too, had obligations. In addition to training apprentices in a trade, they were to provide them with food, drink, lodging, and clothing. A number of indentures specified at least two sets of apparel, one for working and one for Sundays. Most contracts also required the master to provide some degree of education for their apprentice. In some cases, this condition was merely a general requirement to teach the apprentices to read and write, in others a certain number of years was specified. There was a degree of variety in the apprenticeships for boys. Among the skills listed for male apprentices are cordwainer, "marriner," and the "mystery of husbandry." As in England, young girls bound out as apprentices were most likely to be taught the "Business of Houswiving" as was specified in the contract of Elizabeth Hendrickson, apprenticed to Ralph Hunt in Hopewell in $1743 .^{12}$

Although indentures seemed to have been fairly common in most New Jersey communities, in contrast to the practice in England, there is no evidence that any tradesman was ever compelled to accept an indenture. No doubt, some part of this was the absence of any police power on the part of local or colonial authorities to back up a threat of compulsion. But a more important factor was probably the small size of most New Jersey towns. ${ }^{13}$ By and large, the Overseers of the Poor would have been reasonably familiar with the financial circumstances of most of their fellow townsmen and so known who had both the means and need for indentured labor. It is unlikely that most small farmers or craftsmen would have had the financial wherewithal to provide the food, clothing, and other items which an apprentice would have required. But equally, most family farms and businesses, would have had little need for the extra labor. Paul G.E. Clemens and Lucy Simler have noted in their study of rural labor in Chester County, Pennsylvania that only a small number of relatively prosperous farmers took on indentured servants. It seems likely that this situation was paralleled in New Jersey and that most poor children ended up indentured to reasonably prosperous members of the community. Only rarely was a master offered a payment to take on an apprentice, something that was much more

\footnotetext{
${ }^{11}$ Hindle, On the Parish? 191-223, quote on 198.

${ }^{12}$ See indenture contracts located in Hopewell Town Book, Special Collections and University Archives, Rutgers University Libraries, (hereafter RUSC): Benjamin McCollockk (cordwainer), Elizabeth Hendrickson; Indenture of Isaac Osmun (husbandry), James A. Kline Papers, Manuscript Collection \#3, Hunterdon Country Historical Society; Indenture of Jo[illegible] Holmes (mariner), Coll. 22 Cherry Hall Papers, 1682-1941, Box 15, Folder 5, Monmouth County Historical Association Library and Archives. Hindle, On the Parish? 200-218.

${ }^{13}$ John E. Pomfret, Colonial New Jersey: A History (New York: Charles Scribner's Sons, 1973), 192-196.
} 
common in England suggesting that there was perhaps some competition for such labor when it became available. It is also likely that few local communities in New Jersey would have had the funds available to make such payments and so relied on the voluntary acceptance of apprentices. $^{14}$

As in England, masters were also expected to keep to the terms of the indenture. Since indentures were legal contracts, breaking them required a decision on the part of the county courts of General Quarter Sessions. While it is not impossible that an apprentice could have filed legal action against a master, their situation and status made this unlikely. What is more probable is that the parents may have been told by their child that things were not going well and the parents may then have gone to the Overseers of the Poor. Or, in some towns, it is possible that the Overseers themselves were checking up on the condition of the indentures for which they were responsible. Either way, there are a number of cases reported in the county courts of apprentices being released from contracts because of failure on the part of the master, actions that must have been initiated at the local level. In some cases, it was a simple lack of provision, as was the case for Joseph Burwell who had failed to provide his apprentice, John Johnson, with necessary items such as clothing. Johnson was released back into his parents' care. In other cases, it was the failure on the part of the master to provide services which were designed to reduce the likelihood that their apprentices would become public charges in the future. Thus, Isaac Allerton was released from his apprenticeship to Peter Keirgly because Keirgly had neither taught him a trade nor to read and write even though Allerton was "at the age of fifteen years or upwards and has served the sd Keirgly about nine years." The court ordered that Allerton be placed with someone else who would, the court obviously hoped, teach him the necessary skills. Similarly the basis for seeking the annulment of Robert Willis' apprenticeship to Abraham Shotwell was because Shotwell had not taught him to read and write. In this case, the justices also discovered that Shotwell had "immoderately corrected the sd. apprentice without Just Cause." Clearly, while apprenticeships were designed to alleviate the burden of poverty, local communities did not simply forget apprentices once contracts had been signed. ${ }^{15}$

Communities also looked for ways to provide gainful employment for adults who were threatened by, or had already slipped into, poverty. One means, although uncommon, was for a town to support a resident's application for a peddler's license. Peddlers had been regulated by an act of the Assembly in 1730 which required them to obtain a recommendation from the Justices of the Peace of their own county which certified both the person's honesty and residency within the province. Upon receipt of such a recommendation, and the posting of a bond, the

\footnotetext{
${ }^{14}$ Paul G.E. Clemens and Lucy Simler, "Rural Labor and the Farm Household in Chester County, Pennsylvania," in Stephen Innes, ed., Work and Labor in Early America (Chapel Hill: University of North Carolina Press for the Institute of Early American History and Culture, 1988), 106-143, esp. 117. On payments, Thomas Cox of Upper Freehold township was paid £12 to take on Matthew Layland as an apprentice. But even this seems to be an extreme case: the decision was voted on at a special town meeting called at the insistence of the Justices of the Peace of Monmouth County in 1742. See Upper Freehold Poor Book and Town Meetings at the Monmouth County Archives. On the use of indentures in England see: Hindle, On the Parish? 200-218; W.E. Tate, The Parish Chest: A Study of the Records of Parochial Administration in England, $3^{\text {rd }}$ ed., (London: Cambridge University Press, 1969; Chichester: Phillimore \& Co., 1983), 221-226.

${ }^{15}$ All three cases come from the Essex County Common Pleas Minutes, Reel I-295, New Jersey State Archives (hereafter NJSA). Johnson and Keirgly's cases were heard at the September, 1725 sessions, Willis's at the March, 1726 sessions.
} 
applicant could then obtain a license from the governor. Although approval of peddler applications figure regularly in surviving county court books, only a comparatively small number of petitions are still extant. While most of these contain little more than a requisite declaration of honesty and residency, one or two reflect attempts on the part of local authorities to obtain work for residents. Thus, in 1760, the Burlington Court approved a petition submitted on behalf of John Woodside who was "unable to Get an honest Living by his trade as his Health will not permit him to follow it." 16

However, for fairly obvious reasons, peddler licenses were not a solution for most of the poor. If they were the working poor, they were unlikely to have the capital to set themselves up as a peddler. If they were unable to work at a trade or on the land because of poor health, they were unlikely to be able to travel as a peddler. In some cases, local communities turned to tavern operation as a means to provide employment for those whose health threatened to drop them into poverty. A comprehensive bill for regulating taverns was passed by the assembly in 1739 designed to cut down on an increase in vices that were believed to be spawned by taverns and to restore these establishments to their "true and original Design of...accommodating Strangers, Travellers and other Persons, for the Benefit of Men's Meeting together for the dispatch of Business, and for the entertaining and refreshing Mankind in a reasonable Manner." To this end, the Assembly ordered that licenses must be issued only in "open Sessions, held in each County, City or Town corporate, where such Tavern is to be kept" and that applicants needed to have letters of recommendation from freeholders and neighbors as well as to post a bond. ${ }^{17}$

While most of the surviving applications followed a standard format of noting the need for a tavern because of an increase in travelers or a new transportation route, some were soughtimplicitly or explicitly — as a means to prevent poverty. Thus, the Hunterdon County justices were petitioned by a number of residents to grant a license to Mary Mackey in order to provide for the support of herself, her husband William, and their family. Although William Mackey had previously been granted a license, he had "lost the use of his limbs and is very Infirm in his Constitution." The petitioners recognized that his health did not support a renewal of the license. Nonetheless, they noted that the family's financial stability "Proceedeth from the Income of the Tavern" and that this was due "in a Great Measure [to] his Wife's Management." They thus asked the court to award a license to Mary Mackey since the operation of the tavern "may relieve [the Mackey children] from becoming Chargeable." Similarly, a petition from the inhabitants of Windsor in Middlesex County declared that George Hawke was "by misfortune... past Labour, as to support his famely" and therefore asked for a license for him to keep a tavern on the road "Leading from princetown and Maidenhead to Allentown."18

\footnotetext{
16 “An ACT for the preventing of Lotteries, and for regulating Pedlars,” Bush, comp., Laws, II: 416, 417; Burlington County Court of General Quarter Sessions, Petitions for Peddler's Licenses, 1739-ca.1776, NJSA.

17 “An ACT for regulating Taverns, Ordinaries, Inn-keepers and Retailers of strong Liquors,” Bush, comp., Laws, II: 493-498, quotes on 493 and 494.

${ }^{18}$ Hunterdon County Tavern Licenses, 1762-1799 (microfilm), May 8, 1764 and Middlesex County Tavern Applications, Box 3, Folder 77 both in NJSA.
} 
Although not specifically mentioning the threat of poverty as a reason for an application, many petitions can be seen as a proactive attempt to prevent someone falling into poverty. Just as English towns had a long history of supporting widows who applied to be alewives, so New Jersey communities regularly supported applications by widows who applied for tavern licenses. If a woman could operate a tavern it would prevent her and her children becoming chargeable if the husband had died without a substantial estate. For some New Jersey widows, tavern licenses became long-term arrangements. Anne Hall living in the Middletown-Freehold region of Monmouth County was granted a license in a joint petition with Joseph Dorset. It seems likely that Hall ran the tavern for at least the next fifteen years with a number of different men providing surety. Similarly, petitions were made on behalf of the Widow Agnes Heard of Woodbridge, Sarah Dagworthy of Elizabeth, and the Widow Margery Webb of Newton. ${ }^{19}$

Some applications from men can also be interpreted as a proactive move against poverty or social disorder or both. Robert Breden of Sussex County sought a tavern license noting that he "Liveth on a Publick road which is Dayly Frequented by Travilers and as your Petitioner is Put to a great Deal of Trouble to Entertain Maney of them...is not able to Bear such a Burdin." Similarly, Henry Harelocker of Newton (also in Sussex County) was "much Exposed to Company" as was Japheth Byram who was "much Opressd by Travilers." ${ }^{20}$ While these men could have simply refused service to travelers, this would have gone against expectations of hospitality while, at the same time, risking disorder with numbers of wayfarers sleeping in the open. While there was probably some collusion and misdirection in the way in which these petitions were phrased, there was, nonetheless, an implicit appeal to the idea that local residents ran the risk of slipping into poor circumstances if their situation was not addressed.

Obviously, New Jersey towns were primarily motivated in binding out children and seeking peddler and tavern licenses by the financial equation. The more often that the poor, or the potential poor, could be provided with gainful work, the less the town would have to levy in taxes to care for the poor. But providing such opportunities also meant that people were able to work, a not insignificant point in a society which attached both morality and self-worth to the idea of honest work. Nonetheless, despite the effort to provide gainful employment for many of the poor, few could have believed that some amount of direct poor relief would be unnecessary an issue to which we now turn.

\section{Direct Relief}

In allowing for the provision of direct relief, the original poor law of 1709 also authorized the assessment and collection of taxes by which this could be carried out. As to how these funds were to be used, the law required only that they be disbursed in "such a manner as to the said Townships, at their Meetings, seems proper" in order that the "Poor be supplied with necessary

\footnotetext{
${ }^{19}$ Monmouth County Tavern Licenses, Monmouth County Archives. There are applications extant Anne Hall for $1740,1741,1743$, and 1754. While it is always risky to make assumption based on an absence of evidence, such an assumption does not seem unreasonable in this case. Essex County Tavern Applications, Essex County Records, Reel 1-943, Middlesex County Tavern Applications, Box 4 Folder 1, Gloucester County Tavern Petitions, Gloucester County Historical Society Collection, Reel 152 all in NJSA; Hindle, On the Parish? 60.

${ }^{20}$ Sussex County Tavern Licenses, 1753-1769 (microfilm), NJSA. Breden, November, 1758, Harelocker, November, 1756, Byram, August, 1755.
} 
Maintenance." ${ }^{21}$ Although the Assembly had probably hoped that direct relief would make up a smaller portion of caring for the poor, there is some evidence that it became the first resort in many New Jersey towns during the eighteenth century, a trend that had also been observed in England even though there, too, it was contrary to the original aims of poor relief. ${ }^{22}$ Various efforts were made in New Jersey, at both the local and provincial level, to reduce the burden of direct assessment for poor relief. Some simply used the provision within the act that allowed for fines to be collected from the owners of stray animals which had been impounded. Thus, in 1713, Piscataway decided that the owner of any ram running loose around the town was to be fined ten shillings with the money to go to "the use of the poore." Other towns had unique means at their disposal: Burlington township, laying claim to Matennecunk (now Burlington) Island in the Delaware River decided that any money realized from renting the land on the island would go to the Overseers of the Poor. ${ }^{23}$

Nonetheless, most of the funds for direct poor relief came from taxes assessed on town residents. Although the amount of money required for relief increased throughout the eighteenth century, New Jersey towns consistently collected and paid out money to assist the poor in their towns. Usually the amount was determined at the annual meeting in March and collected fairly soon thereafter. Occasionally, a special town meeting would need to be held to raise more funds or address a particular case of poverty. For the most part, however, the Overseers went about their business and presented their books the following year. Town records reveal very few instances of disputes with the Overseers of the Poor over their accounts. For the most part these were arguments over how much should be paid to a particular person rather than whether that person was an appropriate recipient of poor relief. In fact, it was more common that when books were balanced, a town owed money to their overseers. It is likely that the lack of dispute over poor relief at the local level is attributable to the general increase in wealth for most landholders in the colony, the ongoing availability of land, and the colony's role as one of the suppliers of foodstuffs to the empire. ${ }^{24}$

Only rarely did the assembly get involved in the actual collection of poor relief funds. The most aggressive effort came in 1754, when the Assembly attempted to pare back the amount of money spent on poor relief which it seems to have attributed, at least in part, to corruption on the part of the Overseers of the Poor. In a bill passed that year, the Assembly identified the main villains in increasing poor relief as "idle and disorderly Persons coming from the neighbouring Provinces into this Colony." Coupled with this, the "large and extensive" nature of some New Jersey towns made it possible for the Overseers "upon frivolous Pretences, and for their own private Ends" to abuse their power of assessment and collection. It is hard to know whether there actually was an

21 “Act for the Relief of the Poor," Laws, II: 55, 56.

${ }^{22}$ Hindle, On the Parish? 11, 12.

${ }^{23}$ Piscataway Town Book and Burlington Township, NJ, Minutes 1694-1842, both in RUSC.

${ }^{24}$ Among the poor records reviewed are those from Woodbridge, Hopewell, Piscataway, Burlington (all in RUSC); Gloucester, New Hanover, Chesterfield (NJSA); Upper Freehold, Shrewsbury (Monmouth County Archives). On New Jersey as a grain exporter: Peter O. Wacker and Paul G.E. Clemens, Land Use in Early New Jersey: A Historical Geography (Newark: New Jersey Historical Society, 1995), 141, 143; Pomfret, Colonial New Jersey, 194-196. 
increase in "idle and disorderly person" from nearby provinces - presumably New York and Pennsylvania - entering New Jersey. Historians such as Gary B. Nash and Robert E. Cray have noted that commercial activity in Philadelphia and New York was particularly hard hit by the brief respite in the imperial wars in the middle of the 1750s. However, this period was also a boom time for shipbuilding, housing construction, and a number of other activities which would have provided substantial labor opportunities for artisans and other workers in these cities. It is plausible that there could have been a brief period when the number of transients in New Jersey increased, prompting the politicians to resort to the all too familiar crisis legislation. Even if this were the case, it is much less clear how transient laborers were connected to "frivolous Pretences" on the part of New Jersey's Overseers of the Poor. Perhaps the Assembly believed Overseers might identify "disorderly persons" from "Neighbouring provinces" as worthy of relief and pay them some money to move on while pocketing the difference. Whatever the Assembly believed was going on, in order to prevent corruption they mandated that a Justice of the Peace approve any decision by an Overseer to place someone under the care of the town. Further, each town was to purchase a "handsome Folio Book of good Paper" in which the Justice's order would be recorded. But once again, implementation was delegated to local authority: the books were to be checked at the local town meeting each year. ${ }^{25}$

Most of these town poor books contain only a record of monies received and paid. But a handful of notations in some town books can be used to understand exactly how the poor were cared for in New Jersey communities. What emerges from these records is that, for most New Jersey towns for most of the eighteenth century, the poor were dealt with on a very individual basis. The most common means of relief was for the poor to be cared for in the homes of other members of the community, a service for which the hosts were reimbursed by the Overseers of the Poor. Once again, this paralleled but did not precisely duplicate methods used in England. While the poor were commonly boarded with other residents in England, the hosts were normally the local wealthy who were expected to provide the service gratis, one of the responsibilities that came with wealth. ${ }^{26}$ New Jersey towns, with smaller populations, less social stratification, and fewer truly wealthy resorted to a voluntary, compensated approach.

There were no hard and fast rules for the way in which the poor would be boarded out, and towns seemed to adopt a method that was perceived to be most pragmatic for their situation. In some cases, caring for the poor was a short-term arrangement on the part of several hou seholds. Hopewell Overseer Samuel Moore kept Elizabeth Stives in his own house for several weeks during his 1762-1763 term before she moved to Phillip Palmer's and then on to Nathan Drake's. At Shrewsbury, Mary White and her seven children were cared for by Hezekiah Allen for seven and a half months at which point they were taken in by Joseph Potter. In other towns, agreements were made for a full year at the time of the annual meeting. Thus, in 1764, the residents of Woodbridge ordered that the "overseers of the Poor shall take all the Poor into their Charge and agree with any Person as they shall think fit to keep them all one year," instructions which were repeated the following year. In Shrewsbury, Hannah Stout spent two years in the home of Jacob

\footnotetext{
25 “An ACT for the Settlement and Relief of the Poor," Bush, comp., Laws, III: 599 -614, quotes on 599, 604, 605. In many of the town - and county - records still extant the major part of the entries at the annual meeting are taken up with verification of financial transactions, including reviewing the records of the Overseers of the Poor. Cray, Paupers and Poor Relief, 74; Nash, Urban Crucible, 111.

${ }^{26}$ Hindle, On the Parish? 63-65.
} 
Allen before being moved to that of Robert Mecolle. The town of Chesterfield sought to make a transition from short-term to long-term arrangements in caring for the widow Mary Wheatcraft and her children. From 1709 until 1711, the town — or its officers-voted twice a year to renew its care for the Wheatcrafts. Then, in December, 1711, town officers made a four year agreement with Ambrose Field by which he would receive £9-10s per year (to be paid biannually) on the condition that Wheatcraft would not have to "work out of doors except in harvest or hay time." The town also agreed that if Field were to die, the town would resume care for Wheatcraft so that Field's wife "should not be Incumbered." Some towns also used part of their funds to pay third parties to provide services and goods for the poor. Thus Samuel Moore of Hopewell recorded a number of payments to Daniel Moore for shoes for the poor as well as a payment to a Mrs. Armitage for "services done for the poor." 27

There is also evidence that race did not prevent people from receiving relief. The Township of Lawrence determined, even in the face of "a public outcry" that an unnamed black woman was "Chargeable to the town." In this case, she was treated in the same way that other poor were: she was boarded in a number of homes over the course of several years, with her maintenance being paid by the Overseers of the Poor. Under somewhat different terms, William Tullis of Dearfield was paid a total of £4-3-4 for "tending an Old Indian" and for the cost of a subsequent burial. The payment was ordered by the Cumberland County Board of Freeholders without any argument being noted in the records so it seems likely that the Indian was cared for at the order of the county rather than the town. Although two incidents do not establish general policy (nor do they argue against the existence of racism) the fact that they took place suggests that at least some leaders in the colony saw Christian (and legal) duties as transcending matters of race, paralleling observations made by Robert Cray about some New York towns. ${ }^{28}$

As New Jersey residents watched what they perceived to be an increase in poverty from about the middle of the eighteenth century onward, the assembly granted permission for poorhouses and workhouses to be established. The first legislation providing for workhouses in England had been passed in 1722 and delegated the decision to establish a workhouse to the overseers of the poor along with the churchwardens and a majority of the parish inhabitants. New York City had operated an almshouse since 1735 while the New York Assembly had granted permission to construct poorhouses to Southhold in 1737 and East Hampton in 1748, the same year that New Jersey granted approval to Middlesex County to construct a "Work-House and House of Correction." Six years later, authority was granted to the town of Elizabeth to build a workhouse, poor house, and prison in the town. It would seem, however, that de facto poorhouses had at least been considered in the province before this date. As early as 1708, Chesterfield had agreed to build a log house at town expense to house Mary Wheatcraft and her children. Subsequent

\footnotetext{
${ }^{27}$ Woodbridge Township Records, Liber B, and "Memorandum of Monies Paid Out," in Samuel Moore Papers, both in RUSC; Record Book of the Town of Shrewsbury, Monmouth County Archives; Chesterfield Town Records, NJSA.

${ }^{28}$ Lawrence Township Minutes, RUSC; Cumberland County Freeholder Minutes, County Administrative Offices, Bridgeton, New Jersey; Cray, Paupers and Poor Relief, 90, 91.
} 
entries in the towns records suggest that the house was at least planned, although it is not clear if it was ever built or if the Wheatcrafts lived in such a house long term. ${ }^{29}$

In 1758 the Assembly granted blanket permission to all towns within the colony-provided there was a majority vote of the inhabitants - to purchases houses, or material to build houses, for the "Relief of the Poor." A number of towns took advantage of this act, such as Salem, which in 1770 decided to rent a house for the use of the Gillingham family. Just as the English law allowed several small parishes to jointly operate a single poorhouse, so the 1758 New Jersey law allowed any town which was "too small to purchase or hire" a building for use as a poorhouse, to "join together and unite" with other towns in operating a single poorhouse, provided that such an action was approved by the "major Part of Inhabitants" of each locale. As, as early as 1762, Northampton appointed five men to meet with representatives from the towns of Evesham, Chester, and Springfield to look into "erecting a House for the Poor of Said Towns." ${ }^{30}$ But this seems to have been an exception, as there is no indication in surviving records of any rush on the part of most towns to establish cooperative poorhouses.

\section{Conclusion}

This article has examined the ways in which New Jersey communities took care of the poor in their midst. While this generally took place without a great deal of dispute there were occasions when the provision of relief was challenged. The most common point of resistance was when two towns would argue over who was responsible for a particular person. For example, it took the towns of Evesham and Northampton more than four years, beginning in 1757, to determine which of them was financially responsible for caring for "Saml Reeves a Lunatick" although even here, the matter was eventually settled by a committee made up of men from both towns. In contrast the towns of Fairfield and Greenwich in Cumberland County had to take their dispute over the residency of one Richard Lewis to the Court of Common Pleas which determined that Lewis was the responsibility of Greenwich. ${ }^{31}$

Even less common was a decision by local authorities that family members needed to be instructed to carry out their duties before someone could apply for public relief. In 1767, the Essex County Court of Common Pleas that Ezekiel Johnson and Ephraim Baker should each contribute two shillings "towards the Support of sd. Eliphalet Johnston." Two months later, the same court ordered that Enoch Vreeland, the father of Margaret Erwain was to pay ten shillings per week to the Overseers of the Poor in Newark for the support of Erwain and her "infant child." 32 Nonetheless, if the surviving records are any guide, the cases where poor relief was denied were few and far between. Overwhelmingly, eighteenth-century New Jersey towns went

\footnotetext{
29 "An Act to enable the Inhabitants of the County of Middlesex to build a Work-House and House of Correction within the said County, and to make Rules and Orders for the Government of the same," Bush, comp., Laws, III: 130-136; "An Act to enable...the free Borough and Town of Elizabeth to build a Poor House, Work-House, and House of Correction...," Bush, comp., Laws, III: 288-292; Chesterfield Town Records; Cray, Paupers and Poor Relief, 45, 84-86; Tate, Parish Chest, 226-228.

30 "An Act for the Settlement and Relief of the Poor," III: 599-615, quotes on 609; Tate, Parish Chest, 226-228; Salem Township Minutes and Northampton Town Records, NJSA.

${ }^{31}$ Northampton Town Records (1757 - 1761), NJSA; Cumberland County, Court of Common Pleas, Minute Books 1748-1764, Book A, February, 1761, NJSA.

${ }^{32}$ Essex County Common Pleas Minutes, Reel I-925, NJSA, April, 1767 (Johnston) and June, 1767 (Vreeland).
} 
to great lengths to implement poor relief within their bailiwick. Living under laws which reflected those of Britain but within a substantially more diverse cultural structure, the means by which the towns conducted poor relief paralleled practices in Britain and in other colonies, but did not precisely duplicate them. Children of the poor were indentured to other town residents but the contracts were voluntary for both parties and there was no payment to masters from the poor fund. Some poor were boarded out in houses in the community but no householder was compelled to take the poor and those who did were compensated for their service to the community. Nor does any sense of patronization or elite control emerge from the records as historians have noted for South Carolina and Virginia. ${ }^{33}$

In fact, poor relief in New Jersey bears a striking resemblance to that practiced in New England, something that is not surprising given the large number of New Englanders who emigrated to the colony in the late seventeenth and early eighteenth centuries. ${ }^{34}$ Historian Charles R. Lee has noted that poor relief in Massachusetts was centered on the towns rather than the colonial government and that this produced a "characteristic diversity of relief methods" and, furthermore, that this diversity "intensified" as the conditions in the various towns diverged further. ${ }^{35}$ This largely communal approach to poor relief was also practiced in the rural villages on Long Island, many of which had also been settled by New England migrants. ${ }^{36}$

Whatever the motivations were for the New Jersey Assembly to leave most of the details of poor relief in the hands of the towns, it was a fortuitous decision for both the towns and the poor. What emerges from the accounts of poor relief is, primarily, a pragmatic determination to relieve the lot of the poor in the townships of New Jersey. With relatively small populations in most towns, by and large those paying the assessments for poor relief knew the people to whom they were being paid. In this vein, it is surely no coincidence that the first two requests to operate poorhouses, a much less personal form of poor relief, came from relatively densely populated Middlesex County and Elizabeth Town. Robert E. Cray has noted a similar trend in New York Long Island villages maintained their more communal approach to poor relief long after New York City had turned to institutional methods. In a similar vein, Boston and Philadelphia had adopted institutional approaches by the middle of the eighteenth century. ${ }^{37}$ Left responsible for their own poor, townspeople in New Jersey recognized the faces of the local unfortunates whose poverty was not the result of their own failures or shortcomings. In the face of this local need, the townspeople were willing to part with money and services to assist neighbors and friends who had fallen on hard times. When it came to poor relief in eighteenth-century New Jersey, local problems were overwhelmingly solved by local people.

\footnotetext{
${ }^{33}$ Isaac, Transformation of Virginia, 65; Lockley, "Rural Poor Relief in Colonial South Carolina."

${ }^{34}$ Peter O. Wacker, Land and People: A Cultural Geography of Preindustrial New Jersey: Origins and Settlement Patterns (New Brunswick: Rutgers University Press, 1975), 125-135; Pomfret, Colonial New Jersey, 25-28.

${ }^{35}$ Lee, "Public Poor Relief and the Massachusetts Community" quote on 575.

${ }^{36}$ Cray, Paupers and Poor Relief, 45-66.

${ }^{37}$ Cray, Paupers and Poor Relief, 45, 46; Nash, Urban Crucible, 116-122, 160-162.
} 